\title{
ADDITION OF WHITE SHRIMP (Penaeus merguiensis) HEAD EXTRACT TO INCREASE PROTEIN CONTENT IN SHRIMP STICKS
}

\author{
Rabiatul Adawyah \\ Department of Fishery Product Technology, Faculty of Fisheries and Marine Sciences \\ Lambung Mangkurat University \\ Email: rabiatuladawyah@yahoo.co.id
}

\begin{abstract}
The objective of this study was to obtain a proper ratio between the volume of water and the weight of shrimp heads in order to increase the protein content in shrimp sticks. The design used in the study was a completely randomized design (CRD) with treatment groups of 1:1, 1:2, and a control group without the addition of shrimp head extract. Water content, protein content, ash content and organoleptic test were the parameters measured. The results of the study show that the addition of white shrimp head extract in the treatment group with a 1: 1 ratio produced shrimp sticks with a protein content of $12.22 \%$; in the treatment group with a 1:2 ratio $13.44 \%$; and in the control group without the addition of shrimp head extract only $5.54 \%$. The addition of shrimp head extract also produced more preferred flavor compared to the one without the addition of the extract.
\end{abstract}

Keywords: head extract, Penaeus merguiensis, Protein, shrimp sticks, White shrimp

\section{INTRODUCTION}

The farmed shrimp production in South Kalimantan in 2013 reached 619,000 tones, which were obtained from marine fisheries. Shrimp is one of export commodities that can increase non-oil exports and one of the marine species with high economic value. $84 \%$ of exported shrimps is frozen shrimps without heads.

The shrimp heads have not been used optimally, just considered as waste that could lead to environmental pollution. The shrimp head waste is about $40 \%$, and still has nutritional content of about $10 \%$, which is quite high content of protein and contains element of glycine that gives a taste of sweet and savory in shrimp.

The waste of shrimp in South Kalimantan is still not used optimally and only used as the materials for feed, shrimp sauce and shrimp paste. The studies of the utilization of shrimp head waste were the studies about kittin, chitosan, paste/petis and crackers. Based on the above data, this study was conducted to study the addition of white shrimp head extract as a source of protein to increase the protein content in shrimp sticks.

\section{MATERIALS AND METHODS}

The study was conducted for three months at PHP Laboratory, Faculty of Fisheries, Lambung Mangkurat University Banjarbaru. The equipment used in the study was the equipment for making the shrimp head extract for stick processing, the equipment for analysis parameter testing, and organoleptic testing. The main materials were the shrimp heads, materials for stick processing, and chemicals used for each test and product sample preparation.

The other materials used in the study in addition to the ones needed for the analysis were the ingredients for processing shrimp head extract, namely the white shrimp heads and water, and the materials for processing the sticks like onion, garlic, salt, pepper, margarine and eggs.

The procedures for preparing sticks from shrimp head extract are as follows:

\section{Shrimp head extract processing}

Cleaning the dirt from the shrimp heads. Washing the heads with clean water for \pm 1 minute and then draining the heads for \pm 5 minutes. The shrimp head waste was washed and then boiled for \pm 30 minutes with water in accordance with the treatments, namely the ratio of $1: 1$ and $1: 2$ until $50 \%$ of shrimp head extract was finally obtained. 


\section{Shrimp stick preparation}

The shrimp head extract for each treatment was mixed with 250 grams of wheat flour, 15 grams of margarine, 5 grams of garlic, 10 grams of onions, 10 grams of salt, 2 grams of sugar, and 5 grams of refined pepper. One egg was added into the dough while keeping stirred until the dough was blended and became homogeneous. The homogenized dough was shaped into sticks with the size of $0.5 \times 5 \mathrm{~mm}$ and then fried.

\section{Design of experiments}

Experimental method was used in this study. The design was a completely randomized design (CRD) (Srigandono, 1985) with treatment $A$ (control) = the sticks without shrimp head extract, treatment $B=$ the sticks with the addition of shrimp head extract with a ratio of $1: 1$, and treatment $C=$ the sticks with the addition of head shrimp extract with a ratio of $1: 2$. All treatments were repeated three (3) times in order to obtain 12 units of samples. In this study, the observed parameters were the contents of protein, water, and ash (Sudarmadji, 1994) and organoleptic test (Soekarto, 1995). Data were analyzed using Analysis of Varian (ANOVA) followed by the test of Least Significant Difference (LSD) (Srigandono, 1981). The results of the sensory test were tested by a descriptive test, followed by a significant Hoestlt Difference / Tukey test (Larmond, 1977).

\section{RESULTS AND DISCUSSION}

The results of the observation on the shrimp sticks from shrimp head extract consisting of the tests of water content, protein content, ash content and organoleptic as follows:

\section{Water Content Test}

The shrimp head extract with different proportions had a very significant effect on the water content in the sticks (Figure 1). Treatments B - C were significantly different, whereas C - A and B - A showed a highly significant difference. The high level of water content in treatment $B$ and $C$ was due to the addition of water to make the shrimp head extract at the time of making the dough, while in treatment $A$ no water was added into the dough. The addition of water can affect the water content of food because the higher the water given, the higher the water content in the material when the same heating was carried out.

The results of Honestly Significant Difference test between treatment C - A and B - A show that each of these treatments was significantly different because the shrimp head extract used in each treatment had different comparisons. Treatment A was a control that did not use the shrimp head extract. The addition of shrimp head waste extract in liquid form can affect water content in each treatment.

Treatment B - C, based on the statistical test towards the water content of the sticks from shrimp head extract, was significantly different because the provision of shrimp head extract was high at $250-500$ grams, so it effected the water content on each treatment. 


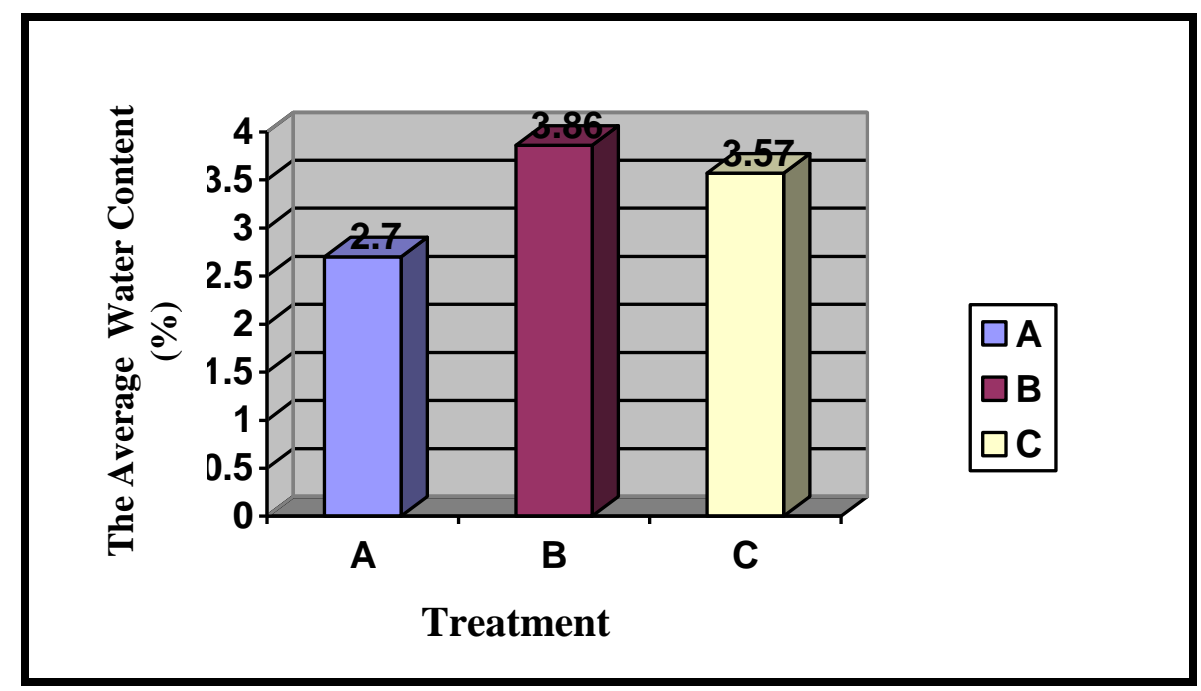

Figure 1. Graph of water content (\%) of Sticks from Shrimp Head Waste Extract.

Water content is an important component because water can affect the appearance, texture and flavor of food (Candra and Adawyah, 2012). The water content affects the quality of food; this is one reason why water is often reduced in processing. The water content in food is closely related to the growth of microbes such as bacteria, fungi and molds. The point indicating whether microbes are still alive or not is not determined by the water content but by the free water contained in the materials called Aw. However, the low water content is the main factor affecting the shelf life of food, and good packaging can help a lot to maintain the condition of a product to be durable (Adawyah and Puspitasari 2012).

Water is important content in food. Water content can affect the deterioration of the material quality both in chemistry and microbiology, as well as the texture on some foodstuffs. In some processing methods for preserving food, like the removal process (drying) or freezing, the water content is very important.

\section{Protein Content Test}

The results of the analysis of the protein content of shrimp head extract with ratios of
$1: 1$ and $1: 2$ were $7.21 \%$ and $6.4 \%$, respectively (Figure 2). It can be seen that the addition of shrimp head extract effects on the protein content of the sticks. For more details, the results of histogram analysis of the protein content of the sticks from shrimp head extract can be seen in Figure 8.

Treatments C - B, C - A and B - A was significantly different, which can be seen in Table 15. It shows that the addition of waste shrimp head extract gave a significant difference to the protein content of the sticks. The higher the concentration was given, the more the protein content tended to increase.

The given treatments met the standard concept of sticks because the protein content was above $5 \%$. This was because the protein content of the used raw materials already exceeded the quality standard of sticks, amounting to $6-7 \%$, so the resulted products met the quality. The protein content of the sticks from the shrimp head extract was high, but it was still lower than those from the shrimp meat. The more the shrimp head extract was given, the higher the protein content in the sticks was. 


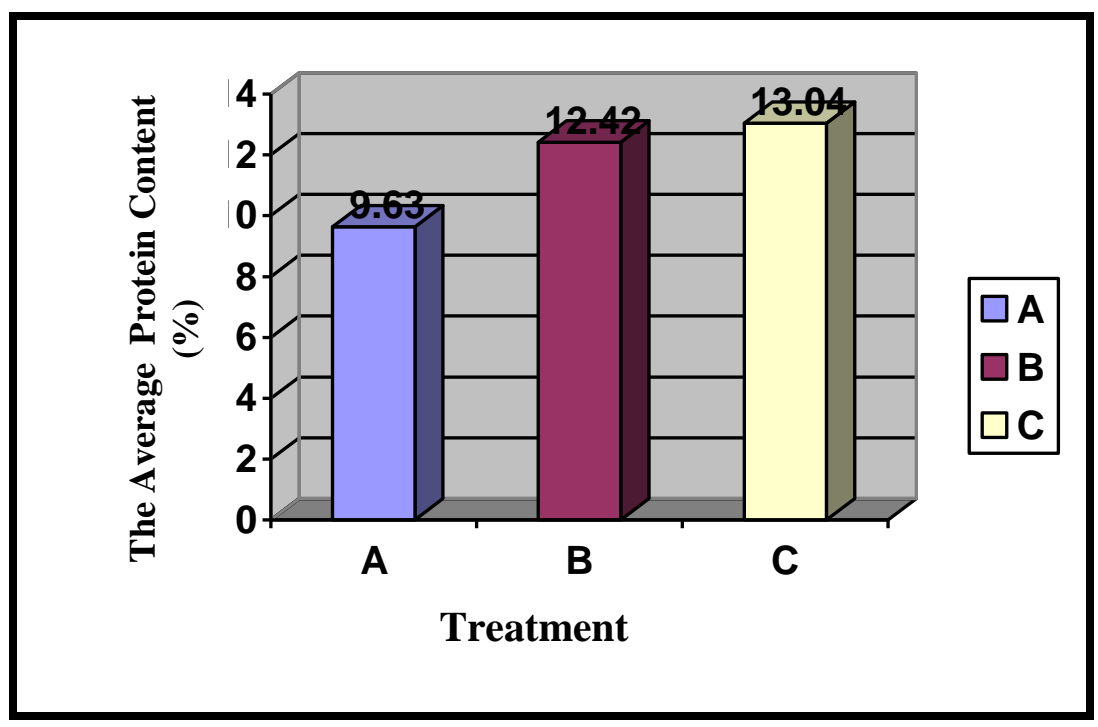

Figure 2. Graph of protein content (\%) of sticks from shrimp head extract

Protein is a nutrient that is essential for our body because this substance, in addition to its function as a fuel in the body, also serves as a builder substance and regulator. Protein is a source of amino acid that is not possessed by fat and carbohydrate. Protein has the properties that make it easily soluble in water and easily changed because of the influence of heating temperature (Jacoeb et al., 2014)

Protein is a source of amino acid that contains the elements $\mathrm{C}, \mathrm{H}, \mathrm{O}$ and $\mathrm{N}$. Some protein molecules contain phosphorus, sulfur, and other types of metallic elements such as iron and copper. The protein molecule is composed of a number of amino acids as raw materials that are related to each other (Winarno, 1984).

The composition of the polypeptide space/chain of a protein molecule may change when the protein is denatured, making its solubility reduced. According to Winarno (1984), denaturation can be interpreted as a change or modification to the structure of secondary, tertiary, and quarter towards the protein molecule, without breaking the covalent bonds. Meanwhile, according to Dewita and Syahrul (2014), the heating process of the protein is considered the most important depending on the temperature, time, water content and the presence or absence of a reducing compound. In the study of stick processing, the most activities carried out were boiling and frying. Frying and boiling are activities for heating materials where the provision of heat can be harmful and beneficial. The heating will make the protein denatured, which means that the structure changes from a strong double form to a loose and open form, making it easier for digestive enzymes to hydrolyze and break it down into amino acids.

The protein content in foodstuff generally determines the quality of food itself. According to Wijayanti et al. (2014), the heat treatment should be optimized so as to maintain the nutritional value and quality of products.

\section{Ash Content Test}

The results of HSD test for ash content in sticks from shrimp head extract in treatment $A, B$, and $C$ were not significantly different (Figure 3). The ash content in the three treatments was almost the same. However, it can be seen from the graph that there were variations in the value of the ash content in each treatment. The different provisions of shrimp head extract increased the ash content in the stick products. The higher the ratio of shrimp head extract, the higher the ash content on the sticks.

The ash content can be used to identify the amount of minerals contained in a material. According to Badaruddin, et al. (1999), the ash content is strongly influenced by the cleanliness of the processing methods as well as the tools used. 


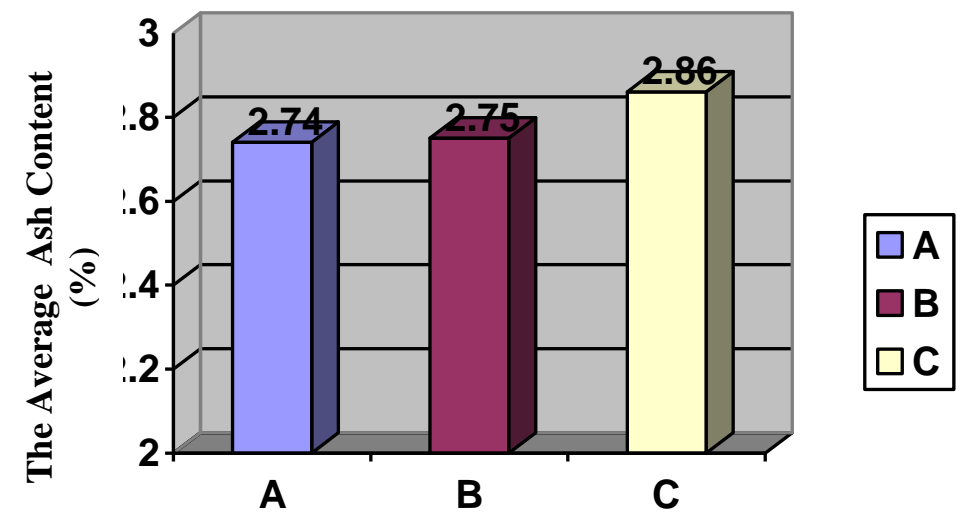

Treatment

Figure 3. Graph of ash content (\%) of sticks from shrimp head extract.

Products with high ash content are less good when consumed. The higher the ash content in a product, the more the organic and mineral substances that cannot be utilized by the body, resulting in a negative impact on health.

The test for ash content in the sticks from shrimp head extract in this study indicated that the higher the percentage of shrimp heads that was added, the higher the value of ash content in the sticks.

\section{Organoleptic Test}

The recapitulation of the average values of the organoleptic test covering color, aroma, texture and flavor tested by the descriptive testing can be seen in the following graph on Figure 4:

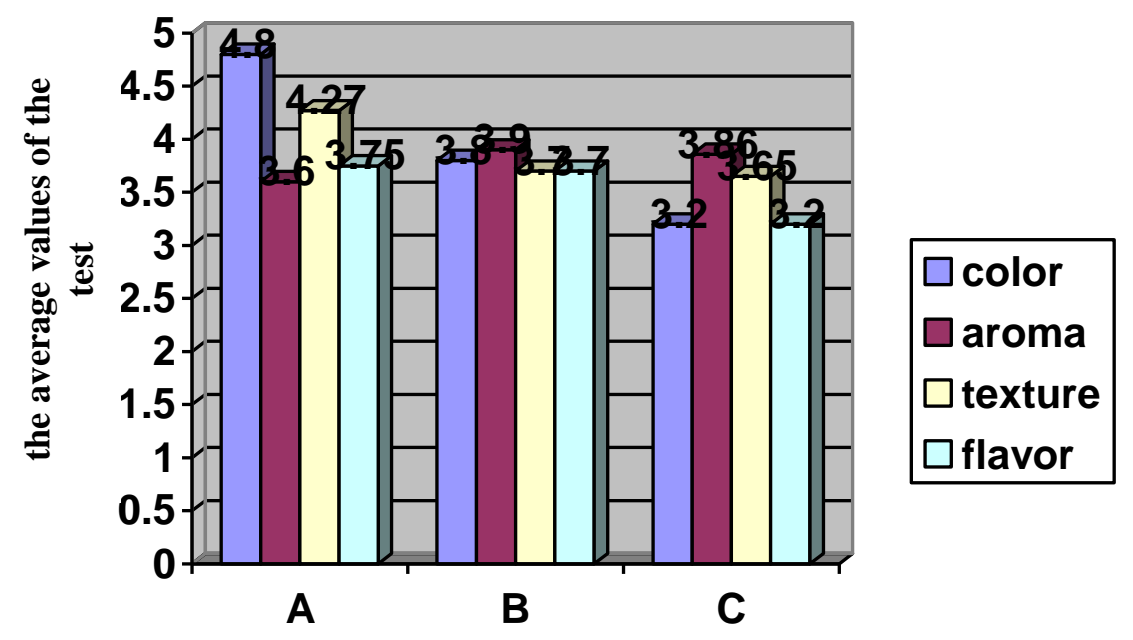

Treatment

Figure 4. Graph of Values of Organoleptic Test (color, aroma, texture and flavor) of Shrimp Sticks from Shrimp Head Extract. 
The results of the descriptive test for the average value of shrimp stick's color showed that between treatment B - A, C - A and C - B there were highly significant difference. The highest averages value was in treatment $A$ (4.8) without the addition of shrimp head extract or control while the lowest average value was in treatment $C$ (3.2), with the addition of 500 grams of shrimp head extract. The addition of shrimp head extract provided a distinctively different color of the stick product. According to Purwaningsih (2011) the color has a meaning and an important role in food commodities. The higher the ratio of shrimp head extract, the lower the level of the color specification of the stick. According to Anggo (2014), the color is the nature of a food that is ascribed to the spread of light spectrum of someone's sensation because of the radiation falling to the sense or the retina of the eye.

The average values of the organoleptic test processed by the descriptive test showed that the aroma values between treatment $B-A$, C - A and C - B were not significantly different, shown in Figure 4. The higher the shrimp head extract, the lower the specification level of the stick's flavor. The highest average level of aroma specification was in treatment B (3.90) due to the exact addition of shrimp head extract, the stick's aroma preferred by consumers. Aroma is defined as an observed the sense of smell to be able to produce odor, smell substances should be able to evaporate, slightly soluble in water and slightly soluble in fat (Anggo, 2014).

The results of the organoleptic test processed by the descriptive test showed that the treatment A - B, A - C significantly affected the texture of the sticks while the treatment $B$ $C$ did not significantly affect the texture of the sticks. The higher the water content, the lower the specification level of the stick's texture. This is because the texture is affected by water and protein in the stick product. The higher the water and protein content, the lower the crispness level of the stick. According to Dendi (2008), the processing of food containing protein, carbohydrate and fat will affect the appearance (aroma, flavor, mouthfeel, aftertaste) and texture (hardness, softness, consistency, firmness, crispness). Texture is the nature of the materials accepted by the consumer with a sense of touch. The most commonly observed characteristics are hardness, cohesiveness and water content (De Man, 1997). Texture is the compound of pressure sensation that can be perceived by the mouth (when bitten, chewed and swallowed) or touched with a finger.

The average values of the organoleptic test processed by the inter-descriptive test indicated that the values of the flavor specification between treatment B - A, C - A and $C-B$ were not significantly different. The results of the organoleptic test showed that the highest average value of flavor was in treatment $C$ (4.2.). The higher the ratio of the shrimp head extract, the higher the specification value of the stick's flavor. This is because the shrimp head extract with high ratio has a typical flavor of shrimp.

The high ratio of shrimp head extract affects the protein content, and the protein also affects the flavor. The flavor is a nerve stimulation generated by the material put into the mouth, felt mainly by the taste and smell nerves, and also by receptors of pain, touch and temperature in the mouth. In general, it has been agreed that there are only four basic flavors, namely sweet, bitter, sour and salty, and the sensitivity to flavor lies on taste buds on the tongue (Aisha, 2003).

\section{CONCLUSIONS AND SUGGESTION}

It can be concluded that the addition of shrimp head extract to sticks had an effect on the protein content, and the flavor was preferred by the panelists. The results show that the addition of shrimp head extract with the ratio of $1: 2$ produced the sticks with highest protein content.

Based on the results of the study, it is also recommended to use shrimp head extract for other products because it is an easily obtained source of protein.

\section{REFERENCES}

Adawyah and Puspitasari (2012). The Addition of Shrimp Head Extract as a Source of Protein Supplement in Processing Crackers. Fish Scintiae 3 (2) $53-65$. 
Aisha, S, (2003). The Efforts in Utilizing Sea Shrimp Waste for Shrimp Sauce Processing by adding Different Concentrations of Cassava Waste. Graduate Program. Lambung Mangkurat University.

Anggo, D.A., Swastawati, F., Ma'ruf, F., and Rianingsih, L. (2014). Organoleptic and Chemical Qualities of Rebon Shrimp Paste with Different Levels of Salt and Length of Fermentation. Journal of Indonesian Fishery Product Processing. 1 (17) 53 - 99.

AOAC (1990). Association of Official Chemists, Analysis: Official Methods of Analysis. $18^{\text {th }}$ Ed. Washington D.C.

Baddaruddin (1999). Quality of Toman Fish Crackers Prepared from Basic Materials of Tapioca Flour, Cassava Flour, Sticky Rice Flour and Sago. Journal of Indonesian Traditional Food (2): 4: 3-11.

Candra and Adawyah (2012). Optimization of the addition of the egg white to increase the expansion of eel fish crackers. Fish Scintiae 2 (2) 43-55.

De Man, J.M. (1989). Food Chemistry 2nd Edition. Publisher ITB Bandung.

Dewita and Syahrul (2014). Fortification of Protein Concentrate of Patin Siam Fish in Sck Amplang and Instant Sago Noddles as Featured Products in Riau. Journal of Indonesian Fishery Product Processing. 2 (17) 156-164.

Isnaini, E. (2002). Addition of White Shrimp to Improve Cracker Quality. The Faculty of Fishery, Lambung Mangkurat University. Banjarbaru.

Jacoeb, M.A., Suptijah, P. and Kamila, R. (2014). Contents of Fatty Acid and Cholesterol, and Description of Meat Tissue of Fresh and Boiled Eels. Journal of Indonesian Fishery Product Processing. 2 (17) 134 143.

Larmond, E.L. (1977). Laboratory Methods for Sensory Evaluation of Food Research Branch. Canada.

Nuraina (2000). The Use of Quail's Egg White to Improve the Expansion Level of
Crackers prepared from White Shrimps. Agritech. (2) $4: 12-20$.

Purwaningsih, S., Garwan, R. and Santoso, J. (2011). Organoleptic Characteristics of Bakasang of Cakalang Offal as a Tradisional Food from North Maluku. Journal of Nutrition and Food. (1) 6: 13-17.

Srigandono, B. (1981). Designs of Experiments. The University of Diponegoro. Semarang.

Sudarmadji, S., Haryono, B. and Suhardi (1994). Analysis of Food and Agriculture. Liberti. Yogyakarta.

Sukarto, T. (1995). Organoleptic Assessment for Food Industries of Agricultural Products. Bharata Karya Aksara. Jakarta.

Wijayanti, I., Surti, T., Agustini, T.W., and Darmanto, Y.S. (2014). Changes in Amino Acid of Catfish with Different Process of Washing. Journal of Indonesian Fishery Product Processing. 2 (17) 134-143.

Winarno, F.G. (1984). Food Chemistry and Nutrition. Publisher PT. Gramedia. Pustaka Utama. Jakarta. 
Rabiatul Adawyah : Addition Of White Shrimp (Penaeus merguiensis) Head Extract To Increase 